\title{
A pedagogia da conquista do espaço público pelas mulheres e a militância feminista de Bertha Lutz
}

Rachel Soihet

U niversidade Federal Fluminense

Programa de Pós-Graduação em História

\section{U $m$ foco sobre o contexto inicial}

Líder do movimento que conseguiu significativos sucessos na conquista de direitos para as mulheres, Bertha Lutz inicia sua campanha no Brasil após seu retorno da Europa, em 1918. Na Inglaterra, interessou-se e manifestou o desejo de participação na campanha feminista, ali desenvolvida antes da guerra, sendo impedida por sua mãe, natural daquele país, que a alertou sobre sua condição de menor e estrangeira. Em seguida, radicou-se na França, onde estudou biologia na Sorbonne, conhecendo naquele país Jerônima Mesquita, que se ofereceu para uma união de esforços no Brasil com vistas a fazer qualquer coisa pelas mulheres. Em aqui chegando, causa curiosidade, repercutindo na imprensa, sua participação no concurso para o Museu Nacional. Um dos candidatos chegou a enviar uma carta para o diretor do Museu, reclamando da participação de uma mulher, o que considerava contra todas as boas normas da moral e da família, e, revoltado, desistiu ele do concurso. Mas Bertha foi classificada em primeiro lugar, constituindo-se na segunda mulher a entrar para o serviço público no Brasil, em que pese a necessidade de um parecer jurídico afirmativo acerca da legalidade da medida. Trabalhou na secretaria do Museu, passando, posteriormente, para o quadro científico. Segundo afirmou em entrevista, a situação brasileira em relação às mulheres não lhe agradava... o que a fez retomar contatos feitos em Paris, objetivando o início de um movimento pela participação das mulheres no espaço público.

De qualquer forma, no Brasil, desde o protesto de Nísia Floresta, na década de 1830, manifestaram-se com mais força insatisfações femininas. Constituiu-se aqui uma imprensa feminina, cujo primeiro periódico, O Jornal das Senhoras, data de 1852, seguindo-se outros, como o de Josefina Álvares de Azevedo, que conjugava duas lutas: a do abolicionismo e a do feminismo. Algumas eram mais moderadas nas suas reivindicações, enfatizavam a importância da educação da mulher, lembrando o seu papel de mãe, ou por uma "questão de requinte espiritual" (Hahner, 1981, p. 35). Nesse particular, lembre-se que era proibida a educação comum dos dois sexos, não só devido à rígida moral católica como, igualmente, devido à certeza da ciência hegemônica na época acerca das diferentes aptidões entre homens e mulheres. Daí a diversidade de currículos a eles desti- 
nados, ocasionando diferenças flagrantes no ensino dos jovens. Enquanto os homens cursavam o ensino secundário, que visava o acesso aos cursos superiores, as moças em sua maioria encaminhavam-se para as escolas normais, destinadas à profissionalização e/ou ao preparo para o lar. Na Escola Normal de Niterói, primeira do gênero da América do Sul, fundada em 1835, as alunas não estudavam álgebra e a geometria limitava-se "às noções mais elementares e de mais frequiente aplicação aos usos elementares da vida" (Júdice, 1994).

Mas havia também aquelas que exigiram uma educação qualificada não em nome da sua responsabilidade familiar, mas porque consideravam-se tão capazes "como o homem para o estudo das ciências", apesar da constante repetição contrária; afirmavam, inclusive a existência de mulheres superiores a muitos homens cientistas; e que escreveram trabalhos que são citados por médicos insignes. A profissionalização como fruto da instrução era apontada como uma necessidade, reivindicando algumas, ainda de forma tímida, a título de complementaridade, pois "nem sempre o trabalho do homem é suficiente para proporcionar à sua família todas aquelas comodidades...”. Outras, mais lúcidas, manifestavam tal necessidade com vistas a que as mulheres atingissem uma posição simétrica no relacionamento com os homens, tornando-se dignas, capazes de uma escolha livre, o que as levaria a desprezar "as adulações pueris de que ainda se mostram ávidas"; não tendo que enfrentar dúvidas quanto a sua fidelidade "porque acabar-se-á a necessidade de fingir e transigir com a artimanha masculina; e só então poderá se assentar ao lado do homem como sua companheira e jamais como sua serva". Havia também aquelas que nem mencionavam o casamento como alvo, ao apontarem a importância do trabalho assíduo e o seu fortalecimento "para as provas da liberdade e para os combates da vida" (Bernardes, 1989, p.138-139, 145, 159).

Não lhes faltava consciência de que assumir tal postura representava um pesado ônus. E o depoimento de uma das mais ativas militantes demonstra-o, ao registrar que "a mulher que estuda, que pensa, ...é objeto de críticas e censuras à sua própria dignidade, e faz parte das distrações, dos cafés e dos bilhares...". Afinal, os médicos com seu domínio do conhecimento científico afirmavam que a mulher foi formada para sentir, como o homem foi criado para pensar e "aquelas que têm apresentado uma inteligência superior, tem sido à custa de suas qualidades femininas". Doenças, comportamento aberrante, esterilidade, degeneração racial eram alguns dos perigos decorrentes da inversão desse princípio, inclusive porque, do desenvolvimento do cérebro feminino, resultava a atrofia do útero (Lombroso \& Ferrero, 1896).

Igualmente, o direito de voto e de elegibilidade foi reclamado, pois, como afirmava Josefina Álvares de Azevedo, no jornal A Família, em abril de 1890, "não se poderá impunemente negar à mulher um dos mais sagrados direitos individuais". Também, reivindicava direitos civis e o divórcio, considerando a indissolubilidade do casamento um "absurdo insuportável, como uma sentença de iniqüidade sobre uma consciência resgatada de culpa”. Assim, mulheres brasileiras, como aquelas da Europa e dos Estados Unidos, reclamavam direitos, reagindo contra a condição a que estavam submetidas. Algumas se rebelaram abertamente, enquanto a maioria se valia de maneiras mais sutis na ânsia de subverter sua situação. Lançavam mão de táticas que lhes permitiam reempregar os signos da dominação, marcando uma resistência. ${ }^{1}$

Observa-se, porém, forte resistência às pretensões de uma alteração nos papéis de gênero. O século XIX teria em toda parte acalentado uma crença nas esferas isoladas da feminilidade e da masculinidade que chegaria aos extremos de uma fé religiosa, e sempre que es-

${ }^{1}$ Vários historiadores descartam a visão unilateral do poder sobre os dominados passivos e impotentes. Como frisa Michel de Certeau, torna-se necessário desvendar as sutilezas engendradas criativamente pelos dominados, com vistas a reagir à opressão que sobre eles incide. E. P. Thompson, embora não estabeleça as mulheres como objeto específico, dedica especial atenção às manifestações cotidianas de resistência dos subalternos. A noção de resistência torna-se, dessa forma, fundamental nas abordagens sobre as mulheres e inúmeras historiadoras têm se baseado nesse referencial no esforço de reconstrução da atuação feminina (Ver Michel de Certeau, 1994, p.41; Thompson. Tradición, revuelta y consciencia de clase. Estudios sobre la crisis de la sociedad preindustrial. Barcelona, Ed. Critica, 1979 , p. 51. 
sas fronteiras foram ameaçadas, argumentos em defesa das absolutas diferenças entre os sexos foram enfiados na brecha aberta. Por outro lado, o processo de agitação, a redefinição da questão sexual, próprio da virada do século, não se limitou às mulheres nas culturas patriarcais. A crise da identidade sexual afetou também os homens, o que explicaria a sua reação desmesurada às postulações femininas de participação na sociedade (Showalter, 1993, p. 21-22).

Tais temores não deixaram de se fazer presentes no país, nas discussões da Assembléia Constituinte de 1891, contribuindo para que fossem rejeitadas as emendas ao artigo 70, visando a explicitar o direito da mulher ao voto. Alguns concluíram pela sua inconstitucionalidade. Outros, porém, alegavam que o elemento feminino estava incluído na categoria “cidadãos brasileiros". Pelo que é dado verificar, conclui-se que o espírito da Assembléia foi o de deixar uma abertura para o tema. Não ousou a referida Assembléia expressar claramente o direito eleitoral às mulheres, numa época de tantas restrições à sua participação; por outro lado, não permitiu também que esta concessão fosse assinalada "expressamente a cidadãos varões", como em alguns estados da União Norte-Americana. Infere-se, portanto, que optou por uma fórmula vaga, imprecisa, que impediria fosse contestada, radicalmente, a capacidade política das mulheres. Sabiam os legisladores que se fosse argumentada a fórmula masculina empregada no direito eleitoral, ter-se-ia, igualmente, que isentar as mulheres de obrigações civis ou de responsabilidade criminal, porque as leis penais sempre se referem aos delinqüentes e criminosos e não às delinqüentes e criminosas. ${ }^{2}$

${ }^{2}$ Eis os artigos da Constituição Brasileira de 1891 que se referem à questão da cidadania: Art. 69 - São cidadãos brasileiros: $1^{\circ}$ ) Os nascidos no Brasil, ainda que de pai estrangeiro, não residindo este a serviço da nação. Art. 70 - São eleitores os cidadãos maiores de 21 anos que se alistarem na forma da Lei. $1^{\circ}$ ) Não podem alistarse eleitores para as eleições federais ou para as dos Estados: $1^{\circ}$ ) Os mendigos, $2^{\circ}$ ) os analfabetos; $3^{\circ}$ ) as praça de pré, excetuados os alunos das escolas militares de ensino superior, $4^{\circ}$ ) os religiosos de ordens monásticas, companhias, congregações ou comunidades de qualquer denominação, sujeitas à obediência, regra ou estatuto que importe a renúncia da liberdade individual. $2^{\circ}$ ) São inelegíveis os ci-
A partir dessa ambigüidade, a advogada Myrthes de Campos, primeira mulher aceita na Ordem dos Advogados, requer seu alistamento eleitoral, argumentando que a Constituição não negava este direito às mulheres. Seu requerimento foi indeferido, o que não a impediu de continuar a sua luta por este direito. Mas foi a professora Leolinda Daltro aquela que primeiro reivindicou o voto de forma organizada. Usando do mesmo argumento sobre sua constitucionalidade, requereu seu alistamento, que lhe foi igualmente negado. Voltou-se, em decorrência, para o campo político, fundando em 1910 o Partido Republicano Feminino, a fim de fazer ressurgir no Congresso o debate sobre o voto feminino. Em novembro de 1917, organizou uma passeata com $84 \mathrm{mu}-$ lheres, surpreendendo a população do Rio, o que pode ter contribuído para que, no mesmo ano, o Deputado Maurício de Lacerda apresentasse na Câmara um projeto de lei estabelecendo o sufrágio feminino, que nem chegou a ser discutido. Na sua exposição de motivos, o Deputado, além de acentuar a comprovada capacidade e eficiência das mulheres ao participarem em todos os ramos de atividade, manifesta-se, igualmente, contrário à interpretação restrita e errônea que excluía as mulheres do termo "cidadãos", presente na Constituição. Em 1919, com o encaminhamento de projeto similar pelo parlamentar Justo Chermont ao Senado, Leolinda Daltro fezse acompanhar por um grupo grande de mulheres a fim de seguir a votação, tática que continuou a ser adotada pelo movimento feminista posteriormente (Alves, 1980, p. 95-96).

Porém a trilha para as mulheres seria espinhosa. Autoridades, políticos em geral, juristas negam-se a considerar positivamente as pretensões de autonomia feminina. Respaldam-se na ciência da época, sinônimo, naquele momento, de verdade absoluta. Apelando para tais convicções e para os prejuízos acarretados à família, já que este era visto como o seu espaço prioritário, buscam

dadãos não alistáveis. Art. 72 - A Constituição assegura a brasileiros e a estrangeiros residentes no país a inviolabilidade dos direitos concernentes à liberdade, à segurança individual e à propriedade, nos termos seguintes: $1^{\circ}$ ) Ninguém pode ser obrigado a fazer ou deixar de fazer alguma coisa senão em virtude da lei. $2^{\circ}$ ) Todos são iguais perante a Lei. 
limitar as mulheres nas suas ações, desejos e emoções, naturalizando determinações histórica e socialmente estabelecidas. Também através de peças teatrais, da literatura, de crônicas e por diversas matérias na imprensa, observa-se oposição ao seu atendimento, inclusive através da ridicularização das militantes. Representam-nas como masculinizadas, feias, despeitadas e, mesmo, amorais; no que conseguiam grande repercussão, não sendo poucos os homens comuns e, também, mulheres que endossavam tais opiniões, através de depoimentos e cartas aos jornais.

\section{A escalada pelo voto}

E é nesse ambiente que Bertha Lutz e um pequeno grupo de companheiras farão a sua campanha que assume caráter hegemônico naquele momento. Organizamse em associações, fazem pronunciamentos públicos, utilizando-se fartamente da imprensa, buscam o apoio de lideranças nos diversos campos, constituindo grupos de pressão visando garantir apoio de parlamentares e de outras autoridades, da imprensa, da opinião pública. Apesar disso, em sua maioria, buscam revestir o seu discurso de um tom moderado. Não apenas porque talvez considerassem que esta seria a forma adequada de expressão feminina, mas, especialmente, por razões táticas.

Ainda em fins de 1918, Bertha envia uma carta à Revista da Semana, na qual se observa este duplo movimento. Critica os homens pelo tratamento dispensado às mulheres, que, sob a capa do respeito, tentavam mantêlas em permanente estado de infantilização. Exige o direito de ser respeitada como ser humano e não como objeto de luxo ou agrado, incapaz de pensar por si. Reconhece, porém, não serem eles os únicos responsáveis pelo estágio em que se encontrava a condição feminina, embora tivessem uma grande parcela, já que "a legislação, a política e todas as instituições públicas" estão em suas mãos. Cabia, contudo, às mulheres lutarem pela sua emancipação, como o fizeram as inglesas e as americanas. E tal luta demandava requisitos básicos, tais como espírito de iniciativa, exercício do trabalho e educação. O exercício do trabalho era determinante, porque lhes propiciava meios de subsistência, livrando-as de uma "dependência humilhante". Constituía, além dis- so, fator decisivo no amadurecimento da personalidade feminina, ajudando-a a "disciplinar a vontade e educar o pensamento". A educação seria o veículo para a consecução desse objetivo. Complementando suas sugestões, Bertha propunha a formação de associações, imprescindíveis para funcionarem como elementos de pressão e para fazer frente às reações surgidas, garantindo "o êxito no rompimento dos tabus e preconceitos relativos à libertação da mulher".

O cuidado em demonstrar sua moderação estava presente ao afirmar que não pretendia uma associação de "suffragettes", que ameaçassem quebrar as vidraças da Avenida, demonstrando sua oposição a certas medidas que caracterizaram o feminismo inglês e norte-americano em determinadas fases. Apressa-se em esclarecer que sua proposta era:

uma sociedade de brasileiras que compreendessem que a mulher não deve viver parasitariamente do seu sexo, aproveitando os instintos animais do homem, mas que deve ser útil, instruirse e a seus filhos e tornar-se capaz de cumprir os deveres políticos que o futuro não pode deixar de repartir com ela.

Contrapõe-se à intocável divisão de esferas entre mulheres e homens, ao enfatizar o exercício do trabalho extradoméstico, mesmo para as mulheres casadas, independentemente da condição do marido. E aí depreendese sua concepção de que o eterno sustento da mulher no casamento corresponderia a uma espécie de comércio sexual, ao recomendar que a mulher "não deve viver parasitariamente do seu sexo, aproveitando os instintos animais do homem". Nesse sentido, propõe uma reformulação na organização da família, que naquele momento constitui-se em algo inovador. Um outro aspecto que se depreende de suas declarações é a crença de que a ascensão feminina resultaria não só em benefícios pessoais, deixando de ocupar "uma posição social tão humilhante para elas como nefasta para os homens e deixariam de ser um dos pesados elos que atam o nosso país ao passado para se tornarem instrumentos preciosos do progresso do Brasil"' (Soihet, 1974, p. 9).

Já em 1919, verifica-se a colaboração de Bertha Lutz na seção "Rio Femina" do Rio Jornal, anunciada como uma das representantes das novas idéias de emancipação do feminismo europeu e norte-americano. Em 
seus artigos, Bertha expõe suas idéias sobre diversas dimensões do feminismo, abrindo um espaço considerável para as questões ligadas às condições de vida das mulheres trabalhadoras.

Apesar da multiplicidade de atividades que conseguiu empreender, abrindo várias frentes de luta, a conquista do voto, de acordo com espírito da época, mereceu prioridade. Acreditava que o acesso aos direitos políticos eram essenciais à obtenção de garantias com base na lei. Em 1919, Bertha funda com um grupo de companheiras a Liga para Emancipação Intelectual da Mulher, que se dispunha a fazer reconhecer os direitos da mulher e sua ampla participação na vida pública, dando arrancada a um movimento no qual se manteve sempre à testa, em que a tenacidade foi a sua marca principal. Esta seria, ao mesmo tempo, segundo uma das historiadoras do movimento, uma das razões da força e da limitação do referido movimento, na medida em que nele predominou sua forte personalidade. E começam, Bertha e suas companheiras, a exercer a citada tática de movimentar a opinião pública e a fazer pressão direta sobre os membros do Congresso. Aproveitavam-se dos laços de amizade existentes entre seus familiares e muitos dos grupos que ocupavam posição de poder para obter simpatia para sua causa e fazer avançar o debate acerca da causa sufragista. Além disso, a capacidade, o brilho intelectual que muitas apresentavam, subsidiando os parlamentares que defendiam suas demandas, igualmente contribuíram na sua maior aceitação (Alves, 1980, p. 105).

Nesse contexto, inaugura-se a década de 1920, que polariza inúmeros descontentamentos que se vinham manifestando ao longo da República e que se expressam em vários movimentos: o Tenentismo, a criação do Partido Comunista, o Modernismo, como também o crescimento do Feminismo. Esses movimentos revelam insatisfações -, relacionadas com o nível econômico, a esfera política - marcada, especialmente, pelo descontentamento com a corrupção característica do sistema eleitoral vigente, postulando um governo realmente representativo -, mas também no que tange ao terreno das idéias, do comportamento, dos valores. Em suma, foi um momento de grande efervescência e busca de soluções para os problemas do Brasil nos mais diferentes âmbitos, observando-se o empenho de inúmeros intelec- tuais em dar ao país uma face nacional e moderna através da valorização de uma cultura que integrasse as diversidades. E o movimento em busca do reconhecimento de direitos das mulheres inseria-se neste bojo.

Em 1922, assiste-se à participação da líder feminista na Primeira Conferência Interamericana de $\mathrm{Mu}$ lheres, realizada em Baltimore. O feminismo brasileiro torna-se, a partir daí, intimamente ligado ao norte-americano, no caso, à NAWSA - National American Woman's Suffrage Association -, vertente conservadora que assumira a liderança naquele país. Terminada a Conferência, as representantes latino-americanas fundaram a Associação Pan-Americana de Mulheres, estabelecendo-se que em cada país latino-americano haveria uma Associação Nacional subdividida em associações estaduais, de acordo com a constituição dos referidos países.

Bertha Lutz recorreu à líder americana, Carrie Chapman Catt, presidente da NAWSA, solicitando ajuda para a elaboração dos estatutos da nova associação no Brasil, a Federação Brasileira para o Progresso Feminino - FBPF -, que substituiu a Liga fundada pouco antes. A associação foi oficialmente inaugurada a 9 de agosto de 1922, sob a presidência de Bertha Lutz e com a presença de Carrie Chapman Catt, a quem Bertha se dirigiu mais tarde como a "mãe espiritual" da entidade. Mas também estiveram presentes as representantes Ana de Castro Osório, de Portugal, e Rosa Manus, da Holanda. Conforme seus estatutos, eram seus objetivos: coordenar e orientar os esforços da mulher no sentido de elevar-lhe o nível da cultura e tornar-lhe mais eficiente a atividade social, quer na vida doméstica quer na vida pública, intelectual e política.

O Art. $3^{\circ}$ discriminava como atingir tais objetivos gerais:

1. Promover a educação da mulher e elevar o nível de instrução feminina.

2. Proteger as mães e a infância.

3. Obter garantias legislativas e práticas para o trabalho feminino.

4. Auxiliar as boas iniciativas da mulher e orientá-la na escolha de uma profissão.

5. Estimular o espírito de sociabilidade e de cooperação entre as mulheres e interessá-las pelas questões sociais e de alcance público. 
6. Assegurar à mulher os direitos políticos que a nossa Constituição lhe confere e prepará-la para o exercício inteligente desses direitos.

7. Estreitar os laços de amizade com os demais países americanos, a fim de garantir a manutenção perpétua da Paz e da Justiça no Hemisfério Ocidental. (Soihet, 1974, p. 13)

A preocupação com a educação e instrução feminina constitui o primeiro dos objetivos; dois deles acentuam o empenho em estimular e garantir o exercício do trabalho para as mulheres, inclusive através de medidas legislativas; quanto aos direitos políticos, constata-se a defesa de que as mulheres estavam incluídas na categoria "cidadãos" presente na Constituição de 1891, cabendo a FBPF assegurar a concretização desse direito; a maternidade e a infância deveriam ser alvo de proteção; a presença do último item num documento concernente a questões próprias das mulheres brasileiras talvez signifique a pretensão dos Estados Unidos de que os países da América se constituíssem num único bloco sob sua direção.

Os Estatutos estabeleceram eleições bienais, embora nada explicitassem quanto às reeleições, o que explica a presença permanente de Bertha Lutz à frente da organização, o que não parece ter incomodado boa parte de seus membros. É sintomática a declaração de uma das militantes, reconhecendo que "Bertha Lutz dirigia integralmente a campanha", aspecto que não se discutia, pois ela "era a mais dedicada", prejudicando a sua carreira profissional na ocasião já que "devotava quase todo seu tempo à luta pelo voto" (Alves, 1980, p. 113). Algumas, porém, como Nathércia da Silveira, saíram mais tarde, criando a Aliança Nacional de Mulheres.

Bertha promoveu em dezembro de 1922 o Primeiro Congresso Internacional Feminino, ao qual esteve presente Carrie Chapman Catt, além de representantes de outros países. Seguindo os conselhos daquela líder, convidou políticos de prestígio para o evento, entre eles, o senador Lauro Müller, Vice-Presidente do Senado, que encerrou a Conferência, reafirmando em seu discurso que a Constituição de 1891 não proibia direitos políticos às mulheres. Confessava, porém, que, na época, o Governo Federal não era favorável às reivindicações feministas. Aconselhou às líderes que procurassem um Governador de Estado disposto a instituir o voto feminino por interpretação da Constituição, o que resultaria na adesão de outras unidades da Federação. "Os homens são como carneiros", disse o Senador, "quando um vai na frente, outros vão atrás” (Soihet, 1974, p. 27).

Surgem filiais da FBPF em diversos estados, assim como outras associações assistenciais e profissionais unem-se à referida entidade. Conferências, crônicas de Bertha e de outras líderes procuram manter a questão do voto feminino na ordem do dia. Em maio de 1923, Bertha Lutz representou FBPF no $9^{\circ}$ Congresso Internacional pelo Sufrágio, reunido em Roma, participando o Brasil pela primeira vez de uma reunião internacional feminina, abrangendo países dos dois hemisférios. Bertha Lutz sugeriu a substituição das expressões "igualdade dos sexos" e "direitos da mulher" respectivamente por "equivalência dos sexos" e "novas responsabilidades da mulher", deixando entrever uma tática nova mais comedida, que ela acreditava mais adequada à consecução dos objetivos visados. Acrescentou, em seguida, que a participação da mulher não implicava competição e sim colaboração (Soihet, 1974, p. 28).

O debate acerca do voto feminino tomou grande impulso, pronunciando-se juristas conhecidos favoravelmente à sua constitucionalidade, além de constituir matéria de comentários nos jornais da época, nos quais Bertha Lutz era personagem requestada. Numa dessas matérias, no jornal A Notícia, a 5 de abril de 1924, lamenta-se a demora do Brasil na adoção da medida, numa época em que mulheres afirmavam-se profissionalmente, atuando nas profissões liberais em diversas atividades que lhes eram anteriormente vedadas. Nesse particular, estávamos atrás da Turquia "da tradicional escravização feminina", que já buscava "conceder à mulher esse direito". O que não impede ao articulista, mesmo num espaço que se mostrava favorável às pretensões femininas, de fazer uma crítica. Acentua que o aspecto físico entre mulheres e homens chegava a confundir: "com o costume da cara masculina raspada, a praga do almofadismo e a nova moda de cabelo curto das senhoras e senhoritas", fato que impossibilitava "saber distinguir os sexos se não fossem as calças e as saias..." Aliás o perigo da indistinção entre os sexos era algo que causava pânico desde há algum tempo... Informava a seguir que o feminismo no Brasil, estava se ar- 
regimentando para um grande movimento de propaganda em favor de seus direitos eleitorais e eletivos.

A campanha manteve-se acesa, embora não fosse fácil a empreitada. No Senado, projeto do Senador Justo Chermont foi aprovado pela Comissão de Constituição, em maio de 1921, recebendo parecer favorável do Senador Lopes Gonçalves, ao identificar as mulheres como atingidas pela cidadania a que se refere a Constituição. Foi encaminhado, posteriormente, à Comissão de Justiça, que deveria opinar sobre a oportunidade da medida. Diante da composição da Comissão, em sua maioria contrária ao reconhecimento do voto feminino, os seus mentores julgaram mais apropriado aguardar melhor oportunidade para a continuidade da discussão. ${ }^{3}$ Nesse ínterim, dois novos projetos foram apresentados, respectivamente, à Câmara e ao Senado. ${ }^{4} \mathrm{O}$ projeto apresentado em 1924 à Câmara, embora incluindo a mulher entre os eleitores, estabelecia uma cláusula restritiva, exigindo a autorização do marido para a mulher casada. As feministas protestaram, argumentando Bertha Lutz a respeito da inconstitucionalidade e ilogismo do mesmo, pois o voto constituía um dever "não podendo ficar na contingência de uma permissão", além do que cabia à mulher "orientar a sua conduta por si própria conduzindose pelo seu próprio cérebro".

Adquiriu novo impulso a questão do voto com a candidatura e eleição do Senador Juvenal Lamartine para Presidente do Rio Grande do Norte. Lamartine foi um dos primeiros políticos conquistados para a causa feminista e manifestou em sua plataforma política, divulgada em abril de 1927, o propósito de contar "com o concurso da mulher não só na escolha daqueles que vêm representar o povo como entre os que elaboram e votam a

\footnotetext{
${ }^{3}$ Baseavam-se no fato de que a Lei estabelecia que, para mudança de matéria constitucional, o projeto de reforma deveria passar por três discussões nas duas casas. Discutido e aprovado em 1921 pelas duas casas, voltou a ser debatido pelo Senado somente em 1927, sem chegar a ser votado, e foi instituído por decreto em 1932, sendo confirmado pela Constituinte em 1934.

${ }^{4}$ Respectivamente, os projetos de Basílio de Magalhães e do Senador Moniz Sodré. Este último incluía explicitamente a mulher no termo "cidadãos", devido ao argumento daqueles que se opunham à medida de que, com relação ao sufrágio, as mulheres não estavam inseridas nessa generalização.
}

lei”. Conseguiu, antes de ocupar o poder, incluir na Legislação do Estado do Rio Grande do Norte um dispositivo estabelecendo igualdade de direitos políticos para os dois sexos. Seguiram-se vinte alistamentos femininos. O precedente aberto deu margem a ampla movimentação da FBPF, que enviou ao Senado uma mensagem contendo duas mil assinaturas. Nela reivindicava-se o voto feminino, acentuando que "desde que uma só exista não há motivo para que não sejam eleitoras todas as mulheres habilitadas no Brasil".

Posteriormente, nas eleições realizadas para preenchimento da vaga criada no Senado com a renúncia de Juvenal Lamartine, votaram algumas das eleitoras. Embora o candidato eleito fosse empossado, a Comissão de Poderes do Senado considerou nulos os votos femininos. Alegou que pretendia evitar o "prejulgamento quanto à sua conveniência e oportunidade", pois o projeto que reconhecia, especificamente, a habilitação política da mulher estava ainda em andamento naquela casa. A FBPF reagiu com um "Manifesto Feminista" à nação no qual eram reclamados os direitos da mulher. Enumerava o citado Manifesto as injustiças a que estava submetida a mulher, negado o reconhecimento de sua existência como ser livre e autônomo, impedida por uma série de estereótipos de se desenvolver plenamente, coagida a obedecer a leis e a pagar impostos em cuja elaboração lhe era vedado intervir. Nesse sentido, acentuava a condição de interdependência entre os sexos e os prejuízos recíprocos acarretados pela supressão dos direitos de um deles, prejuízos extensivos a toda a Nação. Terminava por reivindicar para a mulher o livre exercício de seus direitos e deveres individuais e, especificamente, o voto, único meio legítimo de defender aqueles direitos.

No Rio Grande do Norte, as mulheres, posto que incapazes de exercerem os direitos políticos no plano federal, continuaram a exercê-lo no âmbito estadual. Não só atuaram como eleitoras, como também foram eleitas. Destacou-se a prefeita Alzira Soriano, do município de Lajes. Como antecipara o Senador Lauro Müller, mulheres de outros estados passaram a requerer e obter o alistamento eleitoral. Sobrevindo a Revolução de 1930, dez estados já aceitavam o alistamento eleitoral feminino. Contava, então, a FBPF com filiais em treze unidades da Federação, o que comprova seu esforço na inten- 
sificação da campanha para a consecução dos direitos políticos.

A indicação de Júlio Prestes para suceder a Washington Luís na Presidência da República descontenta Minas Gerais, que se sentiu prejudicada, segundo a lógica do revezamento tradicional da política do "café com leite" da Primeira República. Este processo de ruptura entre as oligarquias que detinham o poder constituiu-se na brecha para a emergência dos descontentamentos que se vinham acumulando, em torno da moralização do processo eleitoral e da emergência de outros segmentos sociais desejosos de participação na vida política. E estes irromperam com a Revolução de 1930.

Até então, as demandas feministas pelo voto não tinham sido atendidas. A FBPF, diante do novo quadro político, decide-se pela realização do II Congresso Internacional Feminista, em junho de 1931. Destacaramse nesse Congresso as decisões relativas às mulheres trabalhadoras, e que atendiam às aspirações da classe operária, propondo medidas protetoras do trabalho, como o estudo de uma fórmula adequada à concessão de licença remunerada à mãe operária ou empregada no comércio por ocasião do parto; salário mínimo; férias; pagamento igual para trabalho igual; rigorosa execução das exigências das autoridades de Saúde Pública e do Trabalho quanto à higiene e à adequação das instalações dos estabelecimentos fabris e comerciais; e a criação do "Bureau" da mulher e da criança, que centralizaria os problemas relativos ao trabalho do menor e da mulher.

Por outro lado, ao encaminharem as conclusões do Congresso ao Chefe do Governo Provisório, as representantes da FBPF enfatizaram sua reivindicação quanto aos direitos de votar e de serem votadas, de influírem na vida pública do país em condição de igualdade para ambos os sexos. Também acentuaram a importância de suprimir a incapacidade civil da mulher casada. Em separado, Bertha Lutz comunicou o apelo, segundo voto por aclamação, do $2^{\circ}$ Congresso Internacional Feminista no sentido de permitir a colaboração da mulher brasileira nos trabalhos da Subcomissão Legislativa, na qual fossem tratadas questões que interessassem diretamente às mulheres.

A fim de atender a uma das principais reivindicações da Aliança Liberal, Vargas nomeara uma comissão para criar uma nova lei eleitoral. Mas, apesar da pressão das feministas, o anteprojeto estabelecia inúmeras restrições ao voto feminino, o que provocou o protesto manifestado por outra liderança do movimento, a engenheira Carmen Portinho. ${ }^{5}$ Ante a afirmação de Vargas de que era ele próprio feminista, porque às mulheres se devia metade da Revolução, ela retrucou: "Sr. Presidente, é por isso que só querem dar a metade do voto? [Ao que Vargas, manifestando estranheza, teria perguntado] Metade como? [E Carmen] Sim, o voto qualificado a determinadas categorias de mulheres. Nós não queremos assim. Ou tudo ou nada!".

Com o Decreto 21.076 de 24 de fevereiro de 1932 estabeleceram-se o voto feminino e o voto secreto. Faltava agora a incorporação desse princípio à Constituição a ser elaborada, o que foi feito com a inclusão do artigo 108 na Constituição de 1934. A FBPF e entidades autônomas filiadas indicaram Bertha Lutz como representante na Comissão de Elaboração do Anteprojeto à Constituição de 1934. Visando mobilizar as mulheres para a campanha eleitoral, além de buscar instruí-las politicamente, a FBPF forma a Liga Eleitoral Independente, a qual promove um curso de Educação Política, constante de conferências de renomados juristas.

Todo o trabalho desenvolvido pela Assembléia Constituinte foi atentamente acompanhado pelas lideranças da FBPF para evitar qualquer retrocesso nas conquistas obtidas, ou que alguma nova medida as pudesse prejudicar. Empenharam-se, por outro lado, na aprovação de determinadas questões que consideravam básicas.

Na verdade, os seus temores não eram infundados. Representantes havia, como o Sr. Aarão Rebelo, que combatiam ferrenhamente o voto feminino, entre outros argumentos, "porque ela segue o pai e o marido". Completava o Sr. Zoroastro Gouveia - "Pior que isso; segue o confessor. O voto feminino foi apenas manobra da di-

\footnotetext{
${ }^{5} \mathrm{O}$ exercício do voto era limitado às mulheres maiores de vinte e um anos, solteiras, viúvas e casadas que auferissem renda própria; àquelas que, por declaração judicial da ausência do marido, estivessem na direção dos bens do casal; às desquitadas e àquelas que tivessem sido deixadas pelo marido por um período maior que dois anos, encontrando-se este "em lugar sabido". Ver Rodrigues, 1962, p. 78.
} 
reita para se garantir contra o surto esquerdista". Outros, como o Sr. Morais Leme, propunham o voto obrigatório apenas para os homens, argumentando que a "mulher ensaia os seus primeiros passos na vida política, e, por isso, o voto dado pelo representante da Sociedade Conjugal deve corresponder ao voto da família".

Uma emenda que propunha a prestação do serviço militar feminino como condição para o exercício do voto (assinada inclusive pela Deputada Carlota Pereira de Queiroz, única mulher eleita para aquela Assembléia), ensejou forte reação. As feministas opuseram-se enfaticamente às restrições que queriam impor aos seus direitos, distribuindo publicações, estabelecendo contatos políticos com parlamentares, ou junto ao chefe do governo. Além disso, romperam nesse momento com o seu comportamento usualmente moderado e vaiaram os deputados que apoiavam a emenda. Esta foi por fim rejeitada.

Ao final da luta, as feministas tiveram suas reivindicações concretizadas na Constituição de 1934. Nela foram incorporadas muitas das sugestões de Bertha Lutz como membro da comissão que elaborara o anteprojeto. Através delas constata-se que a referida líder revela interesse marcante pelos aspectos básicos da sociedade brasileira, ao mesmo tempo que se preocupa em propiciar às mulheres condições de se integrar nos vários planos da vida nacional e internacional. A título de sugestões, reuniu suas propostas numa publicação: Treze Princípios Básicos, em que defende o direito de todo indivíduo ao trabalho dignamente remunerado, à saúde e à educação, sob a responsabilidade do Estado, que deve promover o bem-estar social e a proteção do indivíduo através da criação de órgãos de previdência. ${ }^{6}$

Bertha Lutz foi a candidata indicada para representar o movimento feminista, liderado pela FBPF, na Câmara Legislativa Federal, concorrendo pela Liga Eleitoral Independente, Seção Feminista do Partido Autonomista do Distrito Federal. Obteve em sua cam-

\footnotetext{
${ }^{6}$ Figuraram nas sugestões os artigos que estipulavam a igualdade de direitos, sem distinção de sexo, à nacionalidade, ao voto, à elegibilidade e ao exercício de cargos públicos. No que tange ao trabalho, estabeleciam inúmeras garantias, tais como: a proibição de diferença salarial para um mesmo trabalho por motivo de idade, sexo, nacionalidade ou estado civil; mínimo de conforto, segurança econômica;
}

panha o apoio do Bispo de Niterói, aspecto expressivo das táticas utilizadas por ela e as lideranças da entidade, no sentido de buscar alianças entre os grupos que tradicionalmente a elas se opunham, e inúmeros eram os católicos adversos ao feminismo (Soihet, 1974, p. 50). Nas eleições de 1933, apesar de receber 39.008 votos, Bertha Lutz ficou como suplente do deputado Candido Pessoa, a quem substituiu em 1936, diante do falecimento deste. Integrando a Câmara Federal, destacou-se pela sua intensa e profícua atuação.

\section{Tradicionalismo ou tática?}

Não são poucas as críticas à maneira como Bertha Lutz e suas companheiras da FBPF encaminharam a luta por direitos das mulheres. A brasilianista Susan K. Besse, de forma similar a June Hahner, outra historiadora norte-americana, considera que numa sociedade autoritária, patriarcal e capitalista, elas contribuíram, no máximo, para a modernização das relações de gênero. As feministas dessa vertente teriam evitado assumir posições radicais de contestação em relação aos homens, mantendo-se numa atitude contemporizadora, em nada alterando os padrões da dominação sexual. Assim, buscaram transformar as mulheres em ativas "colaboradoras" dos homens, evitando assumir posições ou adotar táticas que fossem interpretadas como "segregacionistas". Aceitando os valores e normas da sociedade capitalista burguesa, na verdade, teriam ajudado as mulheres a nela se integrarem mais plenamente. Embora, individual e coletivamente, as mulheres dos segmentos médios e elevados colhessem benefícios, para a maioria das mulhe-

instituição do lazer necessário, liberdade de reunião e de associação para os trabalhadores. Determinavam a participação dos mesmos no estabelecimento da legislação e condições de trabalho. Também asseguravam medidas de Previdência Social, reconheciam a maternidade como fonte de direitos, devendo ser amparada pelo Estado. Propunham que os assuntos referentes à maternidade, infância, lar e trabalho feminino fossem tratados por mulheres habilitadas. Tais sugestões foram incorporadas à Constituição de 1934, no Capítulo da Ordem Econômica e Social. Estas propostas expressam as preocupações de institucionalização das reivindicações feministas, mas também a adesão às idéias reformistas, presentes no terreno econômico, no político e no social. 
res pobres os ganhos teriam sido inexistentes. Em suma, as feministas contribuíram para fortalecer e legitimar a nova ordem burguesa, em que pese a conquista de alguns direitos. (Besse, 1996, p.198).

Branca Moreira Alves, cujo trabalho destaca-se por exaustiva pesquisa, tece igualmente inúmeras críticas ao referido movimento, entre elas, a ênfase atribuída ao papel das mulheres como mães e colaboradoras dos homens para justificar a importância na aquisição de direitos. Nesse sentido, o movimento não desenvolveu uma crítica que possibilitasse às mulheres criar sua autoconsciência, que as levasse a questionar as raízes de sua inferiorização - as relações de poder dentro da família. Na perspectiva de Branca, a conquista do voto não teria alterado significativamente a condição da mulher (Alves, 1980, p.155).

Entre outros problemas dessas interpretações, está o de acreditar no poder de uma vanguarda capaz de conscientizar de "fora para dentro" as massas incapazes de desvelarem por si sós sua falta de consciência do processo de dominação. Aliás, o historiador marxista E.P. Thompson é implacável na crítica aos que enaltecem tal vanguarda, que sabe mais do que a própria classe quais devem ser seus verdadeiros interesses. Na situação em pauta, ou seja, no que tange às contradições de gênero, as feministas focalizadas não teriam sido capazes de perceber a conexão existente entre a mística da "missão natural da mulher" e sua inferiorização... E, por força dessa sua incapacidade, foram as grandes responsáveis pelo fato de a maioria das mulheres brasileiras não terem atingido a consciência de gênero. Aliás, concordar com tal suposição seria considerar tais mulheres simples massa informe, capaz de ser influenciada por qualquer guia que surgisse, independentemente de suas condições concretas de existência (Thompson, 1998).

Por outro lado, tais historiadoras, uma das quais militante do movimento feminista no Brasil da década de 1970, incorrem no pecado do anacronismo ao analisar muitas das dimensões da questão de gênero, presentes no movimento em foco, a partir das experiências propiciadas e decodificadas por um outro momento histórico. Criticam, particularmente, nas feministas focalizadas, a mitificação da maternidade na argumentação em prol da aquisição de direitos. Na minha interpretação, a utiliza- ção desse recurso revela uma das táticas próprias a sujeitos submetidos a relações desiguais de poder, que percebem sua incapacidade, em um dado momento, de questionar as prerrogativas da vontade dominante. Pelo contrário, reverenciam as regras estabelecidas, embora busquem perseguir objetivos próprios. Nesse sentido, impossibilitados de lutar abertamente por seus objetivos, tentam alcançá-los fazendo crer aos dominantes que é vontade deles fazer o que eles, dependentes, querem que seja feito e, para conseguir seus objetivos, recorrem a alguns signos consagrados por aqueles (Chalhoub, 1998, p. 98).

Numa outra linguagem, as feministas, com Bertha Lutz à frente, valeram-se de uma tática que mobilizou para os seus próprios fins uma representação "imposta e aceita", mas desviada contra a ordem que a produziu. Portanto, longe de estarem se vergando a uma submissão alienante, construíram recursos com vistas a subverter a relação de dominação (Chartier, 1995, p. 41). Assim, as referidas feministas, ao se utilizarem dessas imagens, embora aceitando certas diretivas estabelecidas para as mulheres pela ordem vigente, buscam sua instrumentalização com vistas a ampliar seu espaço de atuação, o que acreditavam inviável de outra forma. Este pressuposto confirma-se ao examinarmos a análise de Moreira Alves com relação ao movimento norte-americano. Referindo-se às táticas violentas das suffragettes, cita William O'Neill, cuja opinião é de que, com sua falta de tato, atrasaram a obtenção do sufrágio e, como resultado, outras organizações buscaram dissociar-se de tais métodos (Alves, 1980, p. 138).

Moreira Alves, ao examinar os debates no Congresso acerca do voto feminino, desde a Assembléia Constituinte de 1891 até os anos trinta, acentua a recorrência ao argumento da significação do papel das mulheres na família quer pelos opositores, quer pelos defensores da participação feminina. Fato que demonstra o peso desta questão, sendo algo suicida uma atitude de confronto direto com grupos que aprovariam as medidas aspiradas e que expressavam o pensamento dominante naquela sociedade.

Juridicamente, a questão já estaria resolvida na Assembléia Constituinte de 1891, quando o constituinte Almeida Nogueira refutou a interpretação restrita do 
artigo 70, afirmando o direito das mulheres ao voto, pois, para ele, elas estavam incluídas entre os "cidadãos" brasileiros. Mas assim não foi decidido, exigindo-se três discussões em cada Casa, consumindo tempo e esforço consideráveis e atrasando-se em 41 anos o reconhecimento desse direito. Na verdade, os opositores do voto feminino nessa mesma Assembléia desconsideraram a questão jurídica, alegando que o reconhecimento desta reivindicação representaria "a dissolução da família brasileira”. E é em nome da defesa dessa instituição e dos valores a ela ligados que se desenvolve o debate. Serzedelo Correia, mesmo constatando "sua capacidade intelectual e aptidão para exercer o direito de voto", considera que as mulheres não deveriam exercê-lo já que sua missão residiria "em ser o anjo tutelar da família".

Este tipo de argumentação, repetida anos a fio, segundo a própria Moreira Alves, obrigava as sufragistas a reiterarem, a todo momento, a intenção de garantir o desempenho adequado, pelas mulheres, dos papéis familiares. Como juridicamente não se sustentava a argumentação contrária ao voto feminino, na década de 1920, alguns políticos alegavam, para fortalecer sua posição, que, diante do Código Civil, a mulher casada era dependente do marido, não tendo a indispensável liberdade para o exercício do voto. As sufragistas recorriam a importantes juristas que reafirmavam, por sua vez, a cristalina constitucionalidade do voto. O que não impediu que, em 1921, embora reconhecendo a constitucionalidade, o Deputado Heitor de Souza se afirmasse contrário ao voto feminino em nome de uma lei natural que destina o homem à vida pública, cabendo à mulher "a guarda e o zelo do lar doméstico e a tarefa capital da primeira educação da infância...”.

Em 1927 travou-se intenso debate na Comissão de Justiça do Senado, com a última discussão do projeto Justo Chermont, emitindo o Senador Aristides Rocha parecer favorável em discurso assessorado pela FBPF, que também acompanhou a discussão. O Senador Thomás Rodrigues, obstinado opositor do voto feminino, deu voto em separado, adiando o final do debate. Após inúmeras alegações, recorreu ao sentimentalismo, lembrando sua filha "jovem, casta e pura, cujo carinho, cuja meiguice são as suas únicas alegrias...”, para contrapor-se àqueles que o viam como inimigo da mulher.
Acentou a situação real da mulher que, dominando o homem, dominava o mundo, para, enfim, encerrar: "Mantenha ela o lugar que já tem na família e na sociedade" e nada faltará para a sua felicidade que é também a nossa.

Igualmente, também os partidários do voto feminino, tais como o Senador Adolpho Gordo, reiteravam a devoção ilimitada da mulher ao marido e aos filhos, o que só reforçava a certeza de que o voto não se constituiria em obstáculo para a continuidade de sua missão. Assim, não pairava qualquer dúvida sobre a sua capacidade de conciliar o cumprimento de seus deveres políticos com os do lar (Alves, 1980, p. 143-149).

Susan K. Besse, que tantas restrições faz ao movimento, em determinado momento de sua narrativa, reconhece que as táticas desenvolvidas pela FBPF foram cuidadosamente adaptadas ao contexto em que a organização operava. E, mais uma vez, lembro E. P. Thompson, com uma citação exemplar: "a história é a disciplina do contexto e do processo: todo significado é um significado-no-contexto". Portanto, se assumirmos esta premissa como base do fazer histórico, consideramos que aquelas mulheres, conscientes do tempo e do espaço em que estavam inseridas, seguiram a trilha mais adequada para atingir seus alvos. E, continua Besse, nunca a entidade atacou explicitamente a família e a domesticidade como fonte de opressão feminina (embora alguns de seus membros assim pensassem, individualmente); pelo contrário, a organização buscava encorajar as mulheres a observar sua competência no manejo da economia doméstica como valor a ser utilizado na atividade profissional, assim como na participação política. O discurso de Bertha Lutz ao entrar para a Câmara de Deputados é dado como exemplar: "O lar é a base da sociedade, e a mulher estará sempre integrada ao lar. Mas o lar não limita-se ao espaço de quatro paredes. $\mathrm{O}$ lar é também a escola, a fábrica, o escritório. O lar é principalmente o parlamento, onde as leis que regulam a família e a sociedade humana são elaboradas”. Admite Besse que tais declarações implicitamente rejeitavam os papéis de esposa e mãe como uma fonte adequada de auto-realização, status social e segurança econômica, sem diretamente atacar a família ou as mulheres que estavam felizes com sua identidade doméstica. Além disso, numa tentativa consciente de prevenir ataques 
hostis, os membros da FBPF enfatizavam freqüentemente sua feminilidade. Utilizavam estereótipos acerca das diferenças "naturais" entre os dois sexos como justificações das mais efetivas para a entrada das mulheres nas novas áreas de participação social e política. Finalmente, diante da importância desempenhada pela religião na vida da maioria das mulheres, a FBPF também tinha grande cuidado em evitar confronto com a Igreja católica (Besse, 1996, p. 176).

A entrevista de Bertha Lutz, a 17 de dezembro de 1924, ao jornal A Vanguarda, na qual faz uma exposição de motivos acerca da importância do voto feminino, é expressiva deste quadro. Destaca a falta de coerência num regime que se considere democrático, "único regime de governo aceito pelas nações civilizadas", excluir as mulheres de participação. Assim, torna-se injusto, de acordo com tal regime, que não lhes assista o direito de participar na organização das leis e na fixação de impostos, elegendo seus representantes, ou fazendo parte do Poder Legislativo. Inclusive porque as mulheres são obrigadas à observância das leis e ao pagamento de impostos, do mesmo modo que os homens. Além disso, em todos os terrenos e em todos os países, quando lhes é dada a oportunidade de demonstrá-lo, as mulheres evidenciam capacidade idêntica à do homem, sendo ilógico mantê-las em posição subalterna. Abre nesta questão um parêntese, assegurando que, embora a mulher seja equivalente ao homem, possui contudo uma orientação diferente. Volta-se, no domínio das questões públicas, principalmente, com muito maior interesse que os homens, para as problemáticas sociais: a assistência à infância, o combate do alcoolismo, a pacificação do mundo e as boas relações internacionais. Sendo tais questões “importantíssimas na fase atual da civilização", é de toda conveniência a contribuição das mulheres na sua solução. Por outro lado, muitas questões estudadas pelo poder legislativo, câmaras municipais etc., relacionam-se diretamente com o lar, devendo ser levado em conta o ponto de vista da dona-de-casa, aproveitando-se sua experiência de mãe de família, dotada de "conhecimentos preciosos, desconhecidos por outros elementos representados". Ainda, apelando para o papel de educadoras dos filhos, acentua que as mães conscientes dos destinos da Pátria podem inculcar em seus filhos a noção de dever para com ela, evidenciado no voto consciente nas eleições. Afirma que a experiência demonstra que, nos países em que as mulheres conquistaram direitos políticos, elas manifestam grande maturidade, evidenciada no fato de que o eleitorado feminino e as representantes desse sexo no Parlamento "se mantêm alheias às paixões partidárias e às lutas estéreis, dedicando-se às medidas legislativas eficientes e o aperfeiçoamento dos processos de administração". Finalmente, argumenta que o exercício do sufrágio deve ser considerado mais um dever para com a Nação do que um direito, devendo tanto as mulheres como os homens cumprir livremente essa obrigação.

Arguta peça política. A autora articula um discurso no qual mais uma vez busca demonstrar, num meio hostil, o caráter moderado do feminismo local. Apesar disso, a competência das mulheres, adquirida no exercício de suas funções tradicionais, é ressaltada para enfatizar sua maior habilidade na esfera pública no trato de determinadas questões próprias de sua experiência cotidiana, pois, embora a mulher seja equivalente ao homem, possui contudo uma orientação diferente. Disso depreende-se que não estaria disputando aos homens os mesmos espaços de atuação, além de enfatizar o caráter pacífico e maduro da participação feminina despojada de paixões partidárias, o que estaria de acordo com sua $n a$ tureza. Nesse sentido, não há que impedir sua participação que iria enriquecer o panorama político-partidário, não se justificando mantê-la numa posição subalterna.

Vale-se da tática, ação calculada, segundo Michel de Certeau, daquele que "não tem por lugar senão o do outro e por isso deve jogar com o terreno que lhe é imposto tal como o organiza a lei de uma força estranha" (Certeau, 1994, p.100). Ou seja, nas condições em que se desenvolvia a luta feminista no país, como tem sido apresentado ao longo deste trabalho, não havia, naquele momento, espaço para uma outra opção. Havia que exaltar a maternidade, valor uníssono na sociedade brasileira, especialmente para aqueles que ocupavam posições de poder e que tinham acesso aos meios de comunicação na época. Aliás, a própria Branca Moreira Alves, apesar de criticar a todo tempo a trilha escolhida pelo referido movimento, admite, numa aparente contradição, que este feminismo, assim domesticado, era o único possí- 
vel para garantir o reconhecimento das suas reivindicações quanto às reformas básicas. Era o único “que poderia ser aceito pelo sistema político que procurava influenciar e que era veículo para a realização de seus objetivos" (Alves, 1980, p.138).

Mas não apenas entre os parlamentares manifestavam-se acirradas manifestações de oposição à participação feminina. Na imprensa a situação não se afigurava mais favorável ao feminismo. Ao longo do tempo, este vinha sendo objeto de grosseiras caricaturas em crônicas e charges, nas quais se buscava passar a mensagem do terror e do grotesco que representaria a participação de mulheres em esferas consideradas próprias dos homens. Uma das conseqüências seria a desordem familiar, mulheres passariam todo o dia no escritório ou em assembléias, vendo-se os maridos envolvidos nos cuidados com os filhos, atividade para a qual não apresentariam quaisquer habilidades, daí decorrendo a péssima qualidade da alimentação, não cumprimento de horários, o caos doméstico...

Via de regra, tais crônicas enaltecem a dimensão sacralizada das mulheres, representada pela maternidade, acentuam a sensibilidade, específica da mulher, através da qual "dominando o homem, guia as crianças e governa o mundo”. Ressalta-se, afinal, o caráter específico das qualidades femininas, que não passam pela atividade intelectual ou política.

Não concebo a mulher fora do seu ciclo, apostrofando os deuses ou discutindo a origem das espécies. Ela foi feita para domar o homem. Que será da humanidade o dia em que ela, rasgando o peignoir de rendas, envergar o grosso capotão masculino e sair para a rua, não mais com a leve sombrinha de seda, mas com o humilhante cacete do capanga eleitoral? Desaparecerá o encanto dos salões, a alma da paisagem, o amor do lar... (Careta, 1919)

Repetem-se velhos estereótipos acerca da importância de serem respeitados os diferentes atributos dos homens e mulheres, concepção presente na religião, atualizada e sofisticada pelos filósofos iluministas e utilizada pela ciência. O tom da crônica caracteriza-se pela sisudez, em que pese sua excessiva melosidade, até chegar ao seu final, quando lança mão de um artifício por demais vulgar, aquele de que "só as muito feias hão de querer se emancipar... coitadas! as bonitas não", porque a elas nunca faltará um adorador. E, sem mais delongas: "Que nos importa as feias! Salvem-se as belas, que a humanidade se aperfeiçoará".

Aliás, é recorrente a preocupação em acentuar o caráter imprescindível da beleza para as mulheres. A ausência desse atributo representa um pesado ônus, já que, infalivelmente, serão rejeitadas pelos homens, impossibilitando a realização daquela que é considerada a única aspiração legítima para as mulheres - o casamento. O feminismo não deixará de ser utilizado como ameaça à concretização de tal anseio. Um outro cronista, após discorrer sobre uma prática existente na antigüidade, destinada a possibilitar o casamento de moças bonitas mas também das feias, através de leilões, assim termina seu arrazoado: "Talvez fosse esse o único, excelente, maravilhoso meio de acabar duma vez com as sufragistas, as literatas, as neurastênicas, as cochichadeiras e as beatas, horríveis espécies femininas nascidas da classe imensa, descontente, vingativa e audaz das 'vieillesfilles'..." (Fon-Fon, 1918).

Depreende-se desta colocação que as mulheres que se decidem à luta pelo reconhecimento de direitos e buscam disseminar suas idéias fazem-no apenas por frustração. Ou seja, não sendo privilegiadas com a beleza, vendo-se relegadas à triste situação de vieille-fille, vista na época como extremamente humilhante para as mulheres, buscam vingança através do questionamento de sua condição. Em nenhum momento preocupam-se os "donos destas verdades" em lembrar que o casamento e a maternidade, vistos como obrigatórios para as mulheres, constituem-se numa construção predominantemente masculina. Através da religião, da filosofia, das ciências, os formuladores desses saberes buscaram demonstrar a vocação "natural" e única das mulheres para tal forma de existência. E seus herdeiros passam a apresentá-las como "caçadoras de homens" incautos, ridicularizando-as a todo momento quer por essa atitude, quer por seu fracasso, mantendo-se "solteironas".

E, com o passar do tempo, o tom das crônicas não se abrandava. Em uma delas, já em 1930, na Folha da Noite, o autor, que não se identifica, procura explorar a suposta masculinização das mulheres que reivindicavam direitos, um dos estereótipos que lhes era mais atribuí- 
do. Informa que essas esquisitas "senhoras que estão levantando pelo mundo todo o clamor pela conquista dos 'direitos da mulher', não se deveriam chamar 'feministas'. Dever-se-iam chamar 'masculinistas'”. Isto porque, essas ousadas pioneiras vestem-se como homens. Segundo ele, masculinizam-se no traje que passa a descrever:

As sufragistas inglesas, vistas de repente, ou de longe, são figuras ambíguas. A gente custa a saber se a heteróclita criatura de chapelinho de palha, punhos e colarinho duros, gravatinha borboleta, jaqueta igual aos paletós do sexo barbado, sapatos rasos etc. deve ser chamada "miss", "misteres" ou "mister".

Em seguida, detém-se no aspecto físico:

...os modos incisivos, os gestos secos, a voz roufenha, acrescente-se a circunstância dos cabelos cortados e a moda dos homens rasparem barba e bigode, e reconhecemos natural o equívoco, naturalíssimo a confusão.

Todo esse intróito se justificava para atacar aquele que era o objetivo visto por muitos como o mais perigoso subversor da ordem social. "Masculinizadas no tipo, querem masculinizar-se nos direitos". Propugnam a igualdade política e jurídica dos dois sexos, e está claro que propugnariam também a equiparação proliferante. Os mesmos encargos, os mesmos deveres, para marido e mulher. E, aí vinha um outro perigo há muito temido nestas mudanças: "de muito marido sabemos que já serve de ama-seca aos filhos, enquanto a esposa trabalha nas repartições públicas ou alhures".

Insensível para as coisas do coração, inacessível às ruínas e superior às pequeninas vaidades próprias do seu sexo a mulher moderna sem que o perceba se masculiniza para assombro nosso, que espreitamos estupefatos a brusca transformação verificada nos últimos anos. O tipo incrível da Virago aí temo-lo agora, multiplicado e espalhado por todos os cantos da terra... [....] Mulheres nos governos, nas repartições públicas, nos exércitos, nas fábricas - em tudo, enfim, onde havia homens antigamente...

A recorrência de tal discurso torna-se uma constante, inclusive buscando apontar para uma iminente catástrofe, o fim da humanidade, com um inevitável deboche:....a não ser que o Senhor enviasse à terra "um miserável Adão com disposição para servir como escravo a tantas rainhas...”.

Este pensamento, apresentado de forma picaresca, manifestara-se com toda força entre os médicos da virada do século e parecia manter crédito nos anos de 1930. A inteligência, o interesse profissional, o desejo de participação na esfera pública, longe estavam de ser um traço peculiar às mulheres. As mulheres dotadas de forte inteligência, característica masculina, eram incapazes da abnegação, da paciência, do altruísmo que caracterizam a maternidade, função primordial da mulher e garantia da sobrevivência da espécie humana, que tais articulistas buscam reafirmar como ameaçada...

Nesse particular, outro cronista, sob o pseudônimo de "Marmanjo", deplora os desmandos das feministas que exigem direitos, sendo poucas as que, "invadindo o raio de ação do sexo 'besta', queiram acarretar com iguais obrigações”. E, valendo-se de uma série de situações-limites, faz uma caricatura das inúmeras vantagens antigas e novas que elas querem manter; entre outras: prioridade em assentos nos locais públicos, total submissão do marido, invertendo a ordem vista como natural. Ao mesmo tempo, em meio aos seus inúmeros compromissos, fúteis todos eles, acentua o problema da própria sobrevivência da sociedade, seriamente ameaçada, já que "não tem tempo de dar um filho - um só - à pátria" (O Jaguaribe, 1930).

À primeira vista, esta maneira burlesca de apresentar as mulheres empenhadas na luta por direitos não guardaria maiores consequiências, visando apenas divertir o público leitor. Na verdade, porém, percebe-se um aspecto perverso nessas insinuações, o que me faz enquadrar tais colocações numa das modalidades de violência simbólica. Isto porque a reiteração da comicidade na abordagem das reivindicações das feministas tende a difundir uma imagem em voga: a do despropósito das preocupações femininas, ao contrário das masculinas. Por outro lado, muitos, inclusive mulheres, tendem a incorporar esse discurso, divulgado nos diversos meios de comunicação, identificando as feministas, quer como "viragos", feias, frustradas, quer como fúteis, esbanjadoras, amorais, desprovidas do sentimento de mãe e descumpridoras das obriga- 
ções de esposa. Imagens que se contrapõem ao ideal feminino, constantemente reatualizado, de beleza, meiguice, delicadeza, paciência. resignação, o que não poucas vezes leva as mulheres a rejeitar sua inserção no feminismo e até a combatê-lo. ${ }^{7}$

Esta seria uma das explicações para a reticência e, mesmo, rejeição de mulheres de prestígio em assumirem o feminismo. No primeiro caso, lembro Júlia Lopes de Almeida que, posteriormente, já na década de 1920, integrará a FBPF. Ela foi jornalista e autora de livros de sucesso por mais de quarenta anos, desde fins do século XIX até a primeira metade dos anos 1930, momento em que muitas eram as dificuldades para as mulheres firmarem-se no universo das letras. Numa de suas crônicas, censura aqueles que riem da aspiração feminina ao direito de voto, explicitando sua confiança na conquista pelas mulheres do direito em votar nos homens para os supremos cargos da administração pública. E completa: "A questão é de tempo mais nada", apelando para uma das qualidades consideradas como femininas: "as mulheres [...] saberão esperar, porque nas luctas da sua vida intima aprenderam à sua custa a adquirir paciencia, que é a magna virtude para se suportar essas crises".

Termina, porém, ela própria, abrindo mão desse direito: "por ter empenhado o meu às letras, desistirei, se algum dia tal liberdade for às mulheres concedida no Brasil ainda em minha vida de o oferecer à politica eternamente incognita aos meus olhos" (Lopes de Almeida, O Paiz, 1908).

Carmem Dolores, outra literata do início do século, vista por muitos como feminista, assume posição contrária a muitas das reivindicações daquele movimento, especialmente quanto ao direito de voto, considerando inútil a incorporação feminina à política, "forma apenas grotesca de um exibicionismo sem necessidade, que fere

${ }^{7}$ O historiador Roger Chartier identifica a "violência simbólica" como aquela que supõe a adesão pelos dominados das categorias que embasam sua dominação. Nesse sentido, acentua que definir a submisão imposta às mulheres como uma violência simbólica ajuda a compreender como a relação de dominação - que é uma relação histórica, cultural e linguisticamente construída - é sempre afirmada como uma diferença de ordem natural, radical, irredutível, universal. Ver Chartier, 1995, p. 41. preconceitos sem vantagem senão para a vaidade feminina" (Carmen Dolores, O Paiz, 1910).

Mas, também, no período focalizado, mulheres de expressão mantêm-se contrárias à plena participação feminina na vida pública. Um exemplo é o da escritora Francisca de Bastos Cordeiro, que emite sua opinião, em 1927, ao Correio da Manhã: "a mulher pode votar, mas não ser votada...”. Seu argumento é aquele de muitos dos parlamentares, aqui já apresentados, o de que a responsabilidade máxima da mulher consiste na "educação dos homens do futuro: - os seus filhos!”. Esta, seria a mais nobre e melhor maneira pela qual "pode e deve contribuir para a grandeza da nação". A política militante deveria ser praticada apenas por aquelas que já alcançaram "certa idade, a que não constituiu lar, ou a viúva, sem preocupações de filhos a criar quando já passou a idade trágica dos 35 anos".

Não via, porém, no voto feminino, nenhum resultado prático, quer para a mulher, quer para o feminismo, pois todas as vantagens a serem obtidas o serão em conseqüência de natural e lenta evolução. Por outro lado, opunha-se a qualquer participação das mulheres nas lutas ásperas dos parlamentos, por força da incompatibilidade com suas qualidades naturais. Ali "ela se sentirá sempre deslocada ou acabará por perder toda a delicadeza que é a sua melhor arma”. Já a diplomacia era um campo que se adequava às suas qualidades, "onde entrarão em jogo todos os seus elementos de perspicácia, de sutilezas". Também, num Ministério de Beneficências, de proteção à criança e aos desvalidos estaria a mulher no seu elemento... Assim, buscava atribuir o exercício de atividades para as mulheres, de acordo com características acreditadas como decorrentes de razões naturais e não fruto do estilo de socialização. E, observe-se sua ênfase no papel da mulher na educação dos homens do futuro, descartando as filhas mulheres...

Outra das mais conceituadas escritoras da época, Albertina Bertha, autora do livro Exaltação, admite "que ninguém melhor do que a mulher será capaz de desmaranhar a trama de um caso político". E o explica através da crença nas qualidades inatas deste sexo: "sua intuição maravilhosa do concreto, do imediato; o seu espírito de observação [...] a sua presteza em resolver repentinamente qualquer questão...”. 
Considera, apesar disso, que o voto somente cria novas injustiças, desafia rivalidades, suscitando um mundo de irritações e mesquinharias. Diante disso, "a mulher deve repudiar essa generosidade tão pouco generosa e tão pouco aquém de seus merecimentos". E completa, interrogando: "o que de mais surpreendente poderia advir à mulher, senão a sua capacidade de aprisionar o homem ao ritmo de beleza e ao senso de deslumbramento?".

Diante desse quadro, e retomando recomendações de historiadores(as) acerca da significação do exame do contexto, reitero o anacronismo e contradições presentes em muitas das críticas formuladas contra certas limitações do movimento liderado por Bertha Lutz e pela FBPF. A começar por repetidas afirmações de que, ao movimento, por sua natureza burguesa, bastavam conquistas no plano jurídico-político, justificando o seu distanciamento das mulheres da classe trabalhadora. Mas os dados que se seguem, alguns deles presentes na própria obra de Branca Moreira Alves, são testemunhos de que não era bem este o pensamento da militância daquela entidade.

Em 14/08/1934, a FBPF publica um manifesto conclamando as mulheres a elegerem representantes que defendam seus interesses. Ao referir-se às conquistas alcançadas diz: "Isto entretanto foi apenas o começo, porque de muito mais necessita a mulher brasileira...". Também, segundo a ativa militante Maria Luíza Dória Bittencourt: "O voto nunca foi para nós um fim e sim um meio... A campanha começava quando tivéssemos o voto" (Alves, 1980, p. 168). Aliás, a própria Bertha Lutz, logo após a conquista do voto, afirmava: “o sufrágio feminino não é um fim em si mas um instrumento a ser usado para melhorar o status das mulheres". Acrescentava que os ganhos recentes eram precários e a real batalha ainda estava à frente: "as mulheres ainda não tinham entrado na Terra Prometida!” (Besse, 1996, p. 71).

Por outro lado, questiona-se hoje o desapreço manifestado para com as conquistas jurídicas. Não há como negar que estas acarretam princípios de igualdade e universalidade que forçosamente têm que se estender a todos os indivíduos. Além da impossibilidade de se conceber uma sociedade complexa sem leis, sua existência garante que, numa sociedade de classes, elas sejam uti- lizadas pelos dominados na defesa de seus interesses, pois, a condição prévia essencial para a eficácia da lei, em sua função ideológica, é a de que mostre independência, diante de manipulações flagrantes e pareça ser justa. $^{8}$

Além da sua presença efetiva nos meios políticos liderando um pequeno grupo, como tão bem colocam várias autoras citadas, sucediam-se entrevistas de Bertha contra-argumentando as diversas colocações contrárias à participação política feminina. Tratava de criar uma imagem positiva para as propostas tão ferrenhamente combatidas. Aos que aludiam à falta de preparo de alguns elementos femininos para o exercício do voto, lembrava que existiam "muitos homens em semelhantes condições", sem esquecer das mulheres que "pelo trabalho e pelo estudo" tornaram-se aptas, dotadas de "tirocínio e experiência suficientes de elevar as suas vozes a bem do país". Quanto à idealização da mulher como o "anjo do lar", do qual o voto a afastaria irremediavelmente, provocando inúmeros prejuízos, respondia num misto de ironia e lucidez, no artigo "É uma questão de tempo":

Nenhum homem se lembraria de considerar as suas empregadas ou uma mulher do povo, operária e sobrecarregada de filhos, como um anjo do lar. O anjo é apenas a mulher cujos meios lhe permitam dedicar-se unicamente ao homem e, quando é mãe aos filhos, não dispensando contudo outras mulheres talvez menos divinas - para executar os trabalhos menos angélicos e diurnos do lar. (A noite, 11/10/1921)

E completava esclarecendo que o afastamento da mulher do lar não se deveria ao pouco tempo necessário ao exercício do voto. O que afasta a mulher do lar é a necessidade, são as dificuldades materiais da vida, as

${ }^{8}$ Para E.P. Thompson a retórica e as regras de uma sociedade são muito mais que meras imposturas. [...] Podem disfarçar as verdadeiras realidades do poder, mas ao mesmo tempo podem refrear esse poder e conter seus excessos. E muitas vezes é a partir dessa mesma retórica que se desenvolve uma crítica radical da prática da prática da sociedade... A existência dessas regras e a retórica impuseram historicamente algumas restrições ao poder imperial. E lembra neste particular as atuações de Gandhi e Nehru, que delas se valeram na sua luta pela independência da Índia. Ver Thompson, 1987, p. 356-357. 
horas prolongadas nas oficinas, o trabalho mal remunerado, a falta de conforto nos ateliês e nas fábricas, a ausência de tentativas de pôr os seus trabalhos de acordo com a sua função de mãe. Não é o fato de a mulher ser legisladora que causa as circunstâncias atuais, pelo contrário, é a sua ausência.

Por esse discurso, verifica-se a consciência de Bertha dos problemas sociais, que não hesita em apontar, buscando desmascarar os preconceitos e os pretextos para impedir a participação das mulheres na política. Sua última frase, de certa forma, justifica a prioridade que em dado momento deu à conquista do voto. Acreditava que a prática legislativa por parte das mulheres seria um elemento-chave na mudança de condição desses segmentos e mesmo do país. E, como ela, mesmo mulheres engajadas mais à esquerda, como Elena Rocha, consideravam que "primeiro se devia conquistar o voto, devia-se ir por partes, e na época talvez fosse a única coisa possível".

\section{Batalhando por outras conquistas}

A participação de Bertha como membro da Comissão de Elaboração do Anteprojeto da Constituição em, 1932, e as medidas que postulou como parlamentar, comprovam seu interesse por outras questões que dificultavam às mulheres sua plena inserção na sociedade. $\mathrm{Na}$ verdade batalhou em várias frentes, sendo injusto considerar sua atuação apenas com relação ao voto.

O trabalho feminino, inclusive aquele das mulheres pobres, constituiu uma preocupação forte na militância de Bertha Lutz que, também nesse âmbito, sugeriu a criação de associações de classe para as diversas categorias profissionais. Bertha, no começo de sua atuação, segundo o Rio Jornal, aparece como uma das fundadoras da "Legião da Mulher Brasileira", que deveria ser uma "Associação das Mulheres que por necessidade ou por princípio já trabalham, afrontando indômitas a luta". Sua participação efetiva, em 1922, fez-se sentir em favor das empregadas no comércio, intercedendo junto ao Conselho Municipal para a redução do horário de trabalho dessa categoria, que era de treze a quatorze horas diárias, para oito horas. Ainda nesse mesmo ano, reconhecendo as dificuldades das mulheres trabalhadoras e a sua necessidade de auto-suficiência econômica que garantisse sua emancipação, as militantes da FBPF defendem o estabelecimento de creches. Por sua vez, Bertha Lutz reconhece que a sociedade não teria condição de sobrevivência sem o nascimento e a socialização das novas gerações. Assim, exige que não recaia apenas sobre a mulher a responsabilidade dos filhos, requerendo também a garantia, pelo Estado ou pela Sociedade, dos seus filhos pequenos, "independentemente dos caprichos do indivíduo que não pode ou não procura sustentá-los".

Durante toda a República Velha, inutilmente, a FBPF solicitou por várias vezes à Câmara de Deputados um projeto sobre os dispositivos da Conferência Geral do Trabalho de Washington, realizada em 1919, referentes ao trabalho da mulher na indústria. Tal reivindicação implicava a regulamentação de todo o trabalho e o estabelecimento de Leis de Previdência e Assistência, o que só se concretizaria após 1930. Ainda com base nos referidos acordos internacionais, a FBPF pleiteou também para as operárias representação proporcional feminina, entre os membros do Conselho Nacional de Trabalho, instituído por Arthur Bernardes. Sua moção recebe apoio, assinando o documento cerca de 700 mulheres trabalhadoras, representantes das $6.000 \mathrm{em}$ pregadas no comércio, fábricas, ateliês etc. Embora a idéia fosse recebida com aplausos, a falta de vagas foi uma das evasivas de que se lançou mão para rejeitar o apelo (Soihet, 1974).

Como parlamentar, a partir de 1936, desdobrou-se na criação da Comissão do Estatuto da Mulher, da qual foi a presidente, visando a regulamentação dos artigos constitucionais relativos aos assuntos femininos. Bertha Lutz, escolhida presidente da Comissão, ficou encarregada de reunir documentação sobre o assunto, do que resultou a publicação de $O$ Trabalho Feminino - A Mulher na Ordem Econômica e Social. Também the foi atribuído o encargo de elaborar o anteprojeto. Este, seguindo a orientação do II Congresso Nacional Feminino, instituiu o Departamento da Mulher, abrangendo os assuntos relativos ao Trabalho Feminino, ao Lar, à Assistência à Mulher, à Infância e Maternidade e à Previdência Social em todo o território. O referido Departamento teria funções técnico-orientadoras, consultivas e 
executivas. Era previsto um seguro maternal para toda mulher que trabalhasse, entre 18 e 45 anos.

O debate travado com a outra parlamentar, Carlota Pereira de Queiroz, sobre algumas das questões propostas por Bertha Lutz, afigura-se dos mais relevantes, podendo aferir-se a maior lucidez desta última com relação às problemáticas vividas pelas mulheres, mormente aquelas dos segmentos populares.

A deputada Carlota Pereira de Queiroz, divergindo do espírito da criação do Departamento da Mulher, conforme o anteprojeto, apresentou voto em separado. Não via razões para que se isolassem as questões femininas num departamento, depois de conseguida a integração feminina através da concessão do voto e de sua admissão ao exercício de todos os cargos públicos. Criar-seia uma situação de exceção, isolando-se administrativamente os interesses femininos e obrigando os homens de Estado a deles se afastarem. Discordava a deputada Carlota Pereira de Queiroz da autonomia imprimida ao Departamento Nacional da Mulher, atribuindo-lhe funções de verdadeiro Ministério. Considerava indispensável sua subordinação a um dos Ministérios existentes, sugerindo sua dependência ao Ministério da Educação e Saúde. Não considerava, ainda, que a regulamentação do trabalho feminino fosse o problema de maior interesse para a mulher brasileira, dando prioridade às questões sanitárias. Nesse sentido, propunha a criação, no Ministério da Educação e Saúde, do Departamento de Amparo à Mulher e à Criança, primeiro passo para a futura criação de um Departamento de Assistência Social.

A deputada paulista revelava-se distante da realidade brasileira ao considerar o trabalho um problema secundário para a nossa população feminina. $\mathrm{O}$ cunho assistencial que pretendeu imprimir ao Departamento instituído por Bertha Lutz demonstrava uma mentalidade conservadora e tradicional. Preferia "amparar" a mulher carente de recursos a proporcionar-lhe os meios de alcançar a independência através do trabalho.

Bertha apresentava uma visão mais realista dos fatos, ao replicar que de pouco adiantaria a assistência médica gratuita em ambulatórios a pacientes desprovidos de meios de se locomoverem da casa ao hospital e de adquirirem o medicamento receitado. Por outro lado, rejeitava a substituição do Departamento da Mulher pelo Departamento de Amparo à Mulher e da Criança, afirmando que a "necessidade de amparo não é inerente à condição da mulher". Afirmava que a finalidade do movimento feminista não era a de tornar a mulher beneficiária passiva do Estado, mas colaboradora ativa do progresso do país. Contestava a localização da defesa da mulher no Ministério da Educação e Saúde, argumentando que os dispositivos constitucionais que estabeleciam garantias para o lar, trabalho feminino e a maternidade, inclusive o artigo 141, que lhe concedia verba, constavam do Título da Ordem Econômica e Social. Se o legislador constituinte considerasse a atividade feminina e os problemas correlatos como simples expressão de necessidades educativas e sanitárias teria incluído a matéria no título concernente à Família, à Educação e à Cultura (Soihet, 1974, p. 43).

Apesar desse empenho em garantir conquistas para os trabalhadores, particularmente, às mulheres, estas não se somaram às campanhas da FBPF, em termos de participação na luta pelo voto ou comparecendo aos congressos e convenções. Nas entrevistas realizadas por Branca Moreira Alves com militantes simpáticas a uma transformação social mais ampla, estas referiram-se às distâncias sociais entre Bertha Lutz e demais companheiras, em sua maioria profissionais liberais ou membros da burguesia, e as trabalhadoras, dificultando psicologicamente um maior contato. Além desse fator, destaca-se uma falta de maior interesse destas últimas, preocupadas com a sobrevivência e sofrendo a carga da dupla jornada, com a questão do voto. Através das entrevistas, verifica-se que nem todos os membros da FBPF eram conservadores, havia mulheres de esquerda, afirma a líder Maria Luíza Bittencourt, ela própria uma delas. Não queriam, porém, contrariar Bertha Lutz, que temia que uma orientação aberta nesse sentido pudesse prejudicar o movimento que já não era dos mais bem vistos. (Alves, 1980, p. 174).

A segunda parte do trabalho da Comissão compreendeu a elaboração do Estatuto da Mulher, que consistiu na codificação dos direitos femininos, decorrentes do princípio de igualdade incorporado à Constituição. A matéria foi dividida em diversos títulos correspondentes aos estatutos político, econômico-social, cultural, civil, 
comercial e penal da mulher. Através do estatuto econômico regulamentava-se o trabalho feminino, estando nele expressos seus princípios básicos na época.

As questões ligadas à educação mereceram, igualmente, a atenção de Bertha Lutz, que se mobilizou para garantir a entrada de elementos do sexo feminino no ensino secundário oficial, reivindicação vitoriosa em 1922. Pleiteou para a mulher "direitos à instrução idênticos ao homem, a fim de que esta dispusesse dos mesmos meios para o exercício do trabalho e a mesma remuneração". Por outro lado, enquanto membro da Câmara Federal, revela a manutenção das concepções acerca da divisão sexual de trabalho. Demonstrava não ter conseguido libertar-se das representações e práticas que impõem a divisão das atribuições entre os gêneros, apesar de pretender a emancipação feminina. Assim é que, por iniciativa sua, é criada no Ministério da Educação e Saúde uma Divisão de Ensino Doméstico e Vocacional. E ainda foi mais longe no seu ideal de assegurar a domesticidade feminina, ao sugerir a criação de uma Faculdade de Ciências Domésticas e Sociais destinada à formação de "especialistas nos problemas domésticos e sociais e do treinamento de organizadoras futuras para Serviço Federal de Ensino Doméstico e professoras de escolas secundárias". Além disso, o Estatuto Cultural, presente no Estatuto da Mulher, previa "a educação e a orientação feminina, cultural, doméstica, profissional e cívica procurando indicar o caminho do preparo da mulher para o lar, o trabalho e a vida". Já quanto aos direitos civis, sua postura foi das mais avançadas. Afirmava a necessidade de a "mulher [...] ter dentro ou fora do casamento personalidade civil completa, igual à do homem". Através do Estatuto da Mulher, portanto, reconhecia-se às mulheres a plenitude dos direitos civis, afirmando-se a instauração de completa igualdade civil de homens e mulheres, o que se contrapunha ao Código Civil vigente, estabelecido em 1916, que impunha a subordinação da mulher casada ao marido. O pátrio poder seria exercido por ambos os cônjuges, e a mãe, como o pai, transmitiria o nome aos filhos, proposição que até hoje não se estabeleceu. A dissolução do Congresso em 1937, antes da aprovação do projeto, impediu que o Estatuto entrasse em vigor, embora algumas, de suas sugestões fossem adotadas posteriormente.

\section{U ma avaliação}

De forma similar aos diversos movimentos internacionais do gênero, o feminismo aqui focalizado padeceu de inúmeras limitações no que tange ao alcance de seu objetivo: a liberação feminina. Escaparam aos ideais feministas do momento vários dos fatores que impediriam, plenamente, tal liberação, alguns visíveis apenas a partir da década de 1970. Continuava-se a aceitar o exercício de certas atividades como mais adequadas à mulher, por extensão de suas funções maternais. Fato que continuava a reproduzir a concepção acerca da inclinação de cada gênero para as tarefas compatíveis com sua natureza. Sem esquecer que aquelas consideradas mais adequadas ao gênero feminino eram as menos remuneradas. Mantinha-se, em grande medida, a força das representações e práticas que impõem a divisão das atribuições entre os gêneros, comprometendo radicalmente a total emancipação feminina.

Uma forte crítica de Moreira Alves a este movimento foi a de não ter polarizado suas críticas contra a família patriarcal e as relações de poder dentro da família, optando pelo caminho menos contundente da luta no nível jurídico. Na verdade, matizo esta afirmação, pois considero que muito foi questionado. Destaco as propostas de estímulo e reconhecimento da atividade profissional feminina e aquela relativa à instauração de completa igualdade civil de homens e mulheres, mesmo quando casadas, a qual não chegou, infelizmente, a se concretizar.

A conquista dos novos direitos de participação na esfera pública não implicaram, porém, uma reformulação no âmbito das obrigações familiares entre os dois gêneros. Todavia, exigir daquelas militantes, naquele momento, o questionamento da atribuição às mulheres da responsabilidade total pelas atividades domésticas e pela socialização dos filhos seria algo anacrônico de minha parte. É claro, porém, que considerar o espaço doméstico como inerente à mulher, mantendo sua posição desigual na sociedade, constituiu-se em fonte de um processo de violência contra a sua pessoa. Resultaram daí mulheres divididas, culpadas, quando obrigadas a trabalhar fora do lar; considerando sua atividade profissional como algo secundário em relação à atividade princi- 
pal de esposa e mãe, dando lugar à discriminação salarial, profissional e sindical.

Fourier, dado como "socialista utópico", preconizou, ainda no século XIX, a liberação feminina através da instauração de estabelecimentos coletivos acessíveis restaurantes, creches, lavanderias -, que possibilitassem às mulheres partilhar as tarefas que se cristalizaram como suas, além da educação comum aos dois gêneros e a liberdade sexual para ambos. Não se observa, porém, das feministas em pauta, sequer menção à sexualidade feminina, alegando algumas que este era um assunto de foro íntimo.

No que tange ao último aspecto, reconheço a dificuldade, naquele momento, de mulheres dos segmentos médios elevados assumirem uma postura dessa natureza, quanto a um assunto considerado como tabu. Havia a questão política, pois consideravam as outras demandas como prioritárias. E diante das preocupações com a aceitação do movimento pela opinião pública, não ousaram sequer mencionar tal questão. Maria Lacerda de Moura, que logo se desligou do movimento, é uma exceção nesse quadro. Miriam Moreira Leite trouxe à tona, em rica biografia, suas reflexões sobre os diversos aspectos da condição feminina. Assinalou suas posições avançadas, em muitos aspectos similares àquelas das feministas da década de 1970. Mostra-a como uma severa crítica da dupla moralidade vigente, da hipocrisia reinante na organização da família, com seu complemento: a prostituição. Preocupava-se com questões interditadas na época, como a sexualidade e o corpo. Tal diversidade de posições revela a flexibilidade da "jaula", representada pela cultura, possibilitando aos agentes sociais o exercício de uma relativa liberdade, conforme a articulação que estabeleçam dos elementos historicamente à sua disposição. O que é sumamente confortador! As idéias de Maria Lacerda de Moura, consideradas muito radicais, aliadas ao seu aguçado espírito crítico e, principalmente, ao seu excessivo individualismo, contribuíram, segundo Moreira Leite, para sua posição algo marginal (Leite, 1984).

De qualquer forma, apesar de tais limitações, comuns aos demais movimentos feministas do gênero na época, a atuação de Bertha Lutz e da FBPF girou em torno de propiciar às mulheres brasileiras os elementos que possibilitassem sua realização como membro ativo da sociedade. Bertha não se restringiu às reivindicações feministas, interessando-se vivamente pelos diversos aspectos da vida pública. Partilhava das idéias reformistas postuladas pela vanguarda da época, conforme se depreende das sugestões constitucionais que elaborou e mesmo de sua atuação pública. Representou a nova corrente de idéias que contribuiria para modificar o país, a partir de 1930, e, nesse sentido, acreditava na interação entre a ascensão feminina e o progresso do país. É incontestável a validade de sua obra. A partir de 1920, assistimos ao avanço das mulheres em áreas como o trabalho extradoméstico, a educação e a participação na vida social em geral.

Enfim, não há como concordar com a afirmação de que a luta pelos direitos políticos tenha se constituído numa luta inglória, limitada às reivindicações formais do liberalismo burguês, reduzindo-se esta conquista a uma concessão, quando assim interessou à classe dominante, em seu confronto com as massas urbanas que ameaçavam o equilíbrio do jogo político liberal. Uma posição desta natureza desdenha as lutas empreendidas por várias gerações de mulheres já preocupadas com a questão. E, particularmente, quanto a Bertha, importa ressaltar sua ação num momento decisivo, marcando uma ruptura, em meio aos preconceitos nos mais diversos âmbitos, a começar pelo Congresso, nas páginas da imprensa, nos teatros etc. Afinal, penetrar na esfera pública era um velho anseio por longo tempo vedado às mulheres. Significava uma conquista, possibilitando-lhes, segundo Hannah Arendt, assumir sua plena condição humana através da ação política, da qual, por longo tempo, permaneceram violentamente excluídas. Passavam as mulheres a garantir sua transcendência, pois o espaço público, afirma aquela filósofa, não pode ser construído apenas para uma geração e planejado somente para os que estão vivos: deve transcender a duração da vida dos homens mortais, à qual, acrescentamos, também à das mulheres mortais.

RACHEL SOIHET é professora do Programa de Pós-Graduação em História da UFF e pesquisadora do CNPq. Autora de artigos e livros: Condição feminina e formas de violência - mulheres pobres e ordem urbana (1890-1920) (Forense Universitária, 1987); A 
subversão pelo riso, estudos sobre o carnaval carioca da "Belle Époque” ao tempo de Vargas (RJ, Ed. da Fundação Getúlio Vargas, 1998).

E-mail: rachels@nitnet.com.br

\section{ReferênciasBibliográficas}

ALVES, Branca Moreira, (1980). Ideologia \& feminismo. A luta da mulher pelo voto no Brasil. Petrópolis: Vozes.

ARENDT, Hannah, (1981). A condição humana. Rio de Janeiro/São Paulo: Forense Universitária/ EDUSP. Tradução de Roberto Raposo.

BERNARDES, Maria Thereza Cayubi C., (1989). Mulheres de ontem? Rio de Janeiro-Século XIX. São Paulo: T.A.Queiroz editor.

BESSE, Susan K., (1996). Reestructuring patriarchy. The modernization of gender inequality in Brazil, 1914-1940. USA: The University of North Carolina Press.

CERTEAU, Michel de., (1994) Artes de fazer. A invenção do cotidiano. Petrópolis: Vozes. Tradução de Ephraim Ferreira Alves.

CHALHOUB, Sidney, (1998). Diálogos políticos em Machado de Assis. In: CHALHOUB, S., PEREIRA, Leonardo Affonso de M., (orgs.). A história contada. Rio de Janeiro: Nova Fronteira.

CHARTIER, Roger, (1995). Diferença entre os sexos e dominação simbólica (nota crítica). Cadernos Pagu (4), Núcleo de Estudos de Gênero/UNICAMP. Tradução de Sheila Schvartzman.

COSTA, Jurandir Freire, (1979). Ordem médica e norma familiar. Rio de Janeiro: Graal.

HAHNER, June E., (1981). A mulher brasileira e suas lutas sociais e políticas: 1850-1937. São Paulo: Brasiliense. Tradução de Maria Thereza P. de Almeida e Heitor Ferreira Costa.

JUDICE, Norimar, (1994). Texto, mulher e discurso na virada do século: produção e reprodução. Niterói: UFF, mimeo.

LEITE, Miriam Moreira, (1984). Outra face do feminismo. Maria Lacerda de Moura. São Paulo: Ática.

LOMBROSO, Cesare, FERRERO, Guglielmo, (1896). La femme criminelle et la prostituée (traduction de l'italien).

RODRIGUES, João Batista Cascudo, (1962). A mulher brasileira. direitos políticos e civis. Fortaleza: Imprensa Universitária do Ceará.

SOIHET, Rachel, (1974). Bertha Lutz e a ascensão social da mulher. Mestrado em História. Departamento de História. Instituto de Ciências Humanas e Filosofia da Universidade Federal Fluminense.
, (1996). Mulheres em busca de novos espaços e relações de gênero. Acervo. Revista do Arquivo Nacional. Arquivo Nacional, v. 9, n. 1, p. 99-125.

(1997a). História das mulheres: notas sobre o estado atual da questão. In: VAINFAS, Ronaldo, CARDOSO, Ciro F.S, (org.). Domínios da história - ensaios de teoria e metodologia. Rio de Janeiro: Campus, p. 275-296.

, (1997b). História, mulheres, gênero: contribuições para um debate. In: AGUIAR, Neuma (org.). Gênero e Ciências Humanas - desafio às ciências desde a perspectiva das mulheres. Rio de Janeiro: Rosa dos Tempos, p. 95-114.

, (1997c). Violência simbólica, saberes masculinos e representações femininas. Estudos Feministas, v. 5, n. 1/97, p. 7-29. , (1998). La première vague du féminisme brésilien de la fin du XIXe. siècle aux années trente. In: CLIO. Histoire, femmes et sociétés. Femmes, dots et patrimoines, v. 7. Toulouse: Presses Universitaires du Mirail. p. 223 -241.

THOMPSON, E. P., (1979). Tradición, revuelta y consciencia de clase. Estudios sobre la crisis de la sociedad preindustrial. Barcelona: Critica.

, (1987). Senhores \& caçadores. São Paulo: Paz e Terra. Tradução de Denise Bottmann.

, (1998). Costumes em comum. São Paulo: Companhia das Letras. Tradução de Rosaura Eichemberg.

GAY. Peter, (1990). A experiência burguesa da rainha Vitória a Freud. A paixão terna. São Paulo: Companhia das Letras. Tradução de Per Salter.

SHOWALTER, Elaine, (1993). Anarquia sexual. Sexo e cultura no fin de siècle. Rio de Janeiro: Rocco.

\section{Periódicos}

Careta, 11/01/1919.

Correio da Manhã, 30/11/1927.

Folha da Noite, 27/09/1930.

Fon-Fon, 05/01/1918.

O Jaguaribe, 07/09/1930.

O Paiz, 13/01/1908 e 17/08/1910.

A Vanguarda, 17/12/1924. 